\title{
PGGT1B Gene
}

National Cancer Institute

\section{Source}

National Cancer Institute. PGGT1B Gene. NCI Thesaurus. Code C41054.

This gene is plays a role in subcellular protein targeting and the post-translational

modification of certain proteins. 